Discussion Paper No. 670

\title{
ALTRUISM AND THE CARE OF ELDERLY PARENTS: EVIDENCE FROM JAPANESE FAMILIES
}

\author{
Miki Kohara \\ and \\ Fumio Ohtake
}

August 2006

The Institute of Social and Economic Research Osaka University

6-1 Mihogaoka, Ibaraki, Osaka 567-0047, Japan 


\title{
"Altruism and the Care of Elderly Parents: Evidence from
} Japanese Families”

Miki Kohara*, OSIPP, Osaka University, Japan

Fumio Ohtake, ISER, Osaka University, Japan

\begin{abstract}
This paper analyzes what adult children would do for their parents were they frail and in need of long-term care. Focusing on the special case of parents' illness, the paper then investigates altruism in Japanese children. Descriptive statistics show that about $30 \%$ of adult children living separately from their parents provide long-term in-home care, which suggests that a significant number of Japanese children supply care. However, detailed examination reveals that this parental care is not motivated entirely by altruism. We show that children provide parental care when their parents are wealthy enough to meet the costs of nursing.
\end{abstract}

Key Words: Altruism, Informal Parental Care, Within-family Money and Time Transfers, Home Production

JEL Classification Number: D12, D13, J14

\footnotetext{
* Corresponding Author: 1-31 Machikaneyama, Toyonaka, Osaka, 560-0043, Japan. Phone: 81-6-6850-5622. E-mail: kohara@osipp.osaka-u.ac.jp.

The authors are grateful to Naohito Abe, Kenn Ariga, Mototsugu Fukushige, Fumio Hayashi, Charles Yuji Horioka, Yasushi Iwamoto, Takashi Kurosaki, Shuzo Nishimura, Makoto Saito, Katsuya Takii, and seminar participants at Hitotsubashi University, Kyoto University and Osaka School of International Public Policy, Osaka University for their helpful comments. The research for this paper was supported by Grant-in-Aid for Scientific Research number 12124207 from the Ministry of Education, Culture, Sports,
} 


\section{Introduction}

As the population ages, more elderly people need help with daily living. The frail elderly can live in formal care facilities such as welfare facilities, health care facilities and hospitals, or can live independently using formal care services such as home-visitations, drop-in centers and short-stay facilities. According to the 2001 Reports of Survey on Care Service Providers (Ministry of Health, Labor and Welfare, Japanese Government), 2.76\% of the elderly over the age of 65 years live in institutions, such as health care facilities for the elderly (48.5\%), Welfare facilities for the elderly (35\%), and hospitals specially designed for the elderly (16.5\%).

Alternative carers for the frail elderly are their children. As is well known, many Japanese elderly co-reside with their children and their family. The co-residential rate of those aged over 65 years is $48.4 \%$, according to the 2001 Comprehensive Survey of Living Conditions of the People on Health and Welfare (Ministry of Health, Labor and Welfare). This figure is much higher than in other OECD countries, although it has fallen dramatically during the last two decades (70\% in 1990 and 80\% in 1980). Children have various motivations to offer parental care, depending on the parents' and the children's circumstances. Parents' health and living conditions, and children's living and working conditions as well as their innate characteristics can affect children's decisions. The availability of public care systems in residential areas may also be a factor.

Two types of motivation have been mainly examined in the economics literature, one based on exchange, the other on altruism. Both motivate children to care for their parents.

Science and Technology of the Japanese Government. 
That is, we cannot distinguish between the two by looking simply at the strength of family ties. We need to examine the differential: children with the exchange motive would not care for their parents unless the parents had something to exchange, whereas altruistic children would do so regardless of presents from the parents.

The present paper takes up the special situation where parents need long-term care and analyzes motivations of time and money transfers from children to their parents. The paper first describes the theoretical model of altruistic children facing their frail elderly parents' need for care. The comparative statics give us the test implications of altruism. The latter half of the paper investigates the existence of altruism empirically, using a unique survey of Japanese households, The Attitude Survey on Child-care and Long-term Care of Parents, conducted by the Cabinet Office of the Government of Japan in October and November 2000. The survey asks adult children who have not yet experienced parental care needs, "What would you do if your parents needed help in daily life?” The options for the children include money transfers and giving up time to care for their parents.

The question about future possibilities makes it possible to collect enough responses for an empirical investigation while avoiding the common problem with microdata that, unless the sample is targeted, few individuals in the sample face the long-term care of their parents at the time the survey is undertaken. If the survey targets such a sample, then we cannot compare the results with those of a non-targeted sample. The question about the future also makes it possible to examine children's willingness or intention to maintain the status quo. If we examine the sample of individuals whose parents need care now while at the same time undertaking other economic activities such as co-residing and 
working, we cannot strictly distinguish cause and effect. This has been a major endogeneity problem in empirical studies of children's care giving.

The present paper is one of the few studies attempting to solve this endogeneity problem by utilizing such a unique aspect of the data set. Moreover, the transfers investigated in this paper cost not only money but also time. Thus, we can examine children's overall behavior on transfers to their parents using a general empirical method.

Another contribution of this paper is to comment on the existence of altruism in Japanese families, which are usually thought to have strong ties. As mentioned, strong family ties do not always mean altruistic behaviors by family members. They may be the result of selfish motivation. The results for Japan should be an interesting example for research on altruism and within-family transfers in other countries. The implications are important not only for economic but also for sociological studies on household links.

Among the main findings of the paper, the descriptive statistics show that about $30 \%$ of children living separately from their parents offer parental care when the parents need it. However, further investigation reveals that this parental care is not inspired by altruism. That is, children give parental care when their parents are wealthy enough to meet the cost of their demand for nursing.

The paper is organized as follows. The next section summarizes the existing literature on intergenerational transfers. Section III describes the theoretical model of parental care by altruistic children and derives the test implications on altruism. Section IV explains the empirical models used to test for the altruism implied by children's parental care. Section $\mathrm{V}$ provides an overview of the Japanese elderly situation using macrodata on money and time transfers within families. Section VI explains the data used in the paper, and Section 
VII reports the results. The last section concludes.

\section{Existing Literature}

Altruism is one of key factors in explaining intra-family transfers. Altruistic households maximize overall family utility subject to a family budget constraint, so that children transfer more money to parents in financial difficulties, once controlled for children's income. Schoeni (1997), using a Panel Study of Income Dynamics, finds some evidence of altruism among U.S. families. Bernheim et al. (1985) explains intergenerational transfers by not altruism but strategic bequest motives. They show that the number of parent-child contacts increases with parental wealth, since wealthy parents can derive care or attention from their children using the possibility of future bequests. Cox (1987) finds similar behavior, accounted for by “exchange motives”: parents transfer money in exchange for care by their children. Exchange motives, which broadly include strategic bequest motives, indicates that children are more likely to care for their parents when their parents have assets to bequeath in exchange. Cox and Rank (1992) find further evidence to support exchange motives. Cox and Stark (1995) show that visiting, compared to money transfers, is more direct and visible to parents to secure the exchange or to demonstrate successfully. ${ }^{1}$ Thus, not only money but also time is an important

\footnotetext{
${ }^{1}$ As another explanation, Cox and Stark (1995) point out the existence of a demonstration effect: adult children who have (grand) children visit their parents more frequently, expecting that their own children (the grandchildren of their elderly parents) will do likewise.
} 
transfer within a family. The present paper examines transfers from a child to the parent in a sense of time as well as money.

It is difficult to examine the cause and effect of child-parent transfers. There are many general transfers and many simultaneous decisions for economic agents. One way to diminish the difficulty is to focus on a special change occurred in family, say illness of a parent. The study by Bernheim et al. (1985) focuses on the attention paid by children to their parents when they are in poor health. They show that children do not focus more attention on their parents when they are in poor health unless the parents are wealthy and support strategic bequest motives. Pezzin and Schone (1997) also reject altruism (income pooling) by showing that informal care given by children increases with household non-labor income. By contrast, Sloan et al. (1996) find that children care more for cognitively unaware parents, and conclude that wealth is not important if one controls for parents’ awareness. Sloan et al. (1997) further examine hours of care using better data on parents' assets and incomes and obtain the same result. Pezzin and Schone (1999) use an endogenous switching model to examine whether daughters provide informal parental care and supply labor. They find that parents' assets do not affect the provision of informal care by children, but that other characteristics of parents greatly affect informal care provision. The present paper takes up a special situation where parents need long-term care.

There is no direct examination of child-parent care-giving, nor consistent result on the existence of altruistic motives behind general intergenerational transfers in Japan. Hayashi (1995) rejects the existence of mutual altruism by finding no evidence of consumption neutrality between child-households and parent-households. Supporting 
non-altruistic behaviors, Ohtake (1991), Ohtake and Horioka (1994), Yashiro (1993), and Komamura (1994) find a positive relationship between parents' economic situation and co-residence with children. In contrast, Ando et al. (1986), Takayama and Arita (1996), and Iwamoto and Fukui (2001) show a negative relationship between them.

The reseaches on Japanese households often have data difficulty: we can hardly obtain adequate micro-data for empirical investigations. All the existing Japanese literature lacks information on either parents' or children's characteristics. The present paper utilizes both parents' and children’s characteristics of Japanese families. It would give an interesting result for on-going arguments on exchange motives.

\section{Theoretical Model of Parental Care}

We describe a child's transfer behavior to the parent who needs long-term care. General family-transfer models are converted into time and money transfers from children to their parents. Our focus is to examine the demonstration of altruism in the specific case of care for frail elderly parents. Therefore, we derive the null hypothesis of the existence of altruism from children towards their parents, based on the theoretical model of altruistic children's behaviors, but not based on mutual altruism or family bargaining, which are used in some analyses of family transfers.

Suppose that children $(k)$ and parents $(p)$ live independently. When the parents become ill and need help in daily life, their children decide whether to take care of their ill parents or/and give financial support. Parents can buy care services in the market and/or receive care services from their children. Parents' Health, $G$, is “produced” by market care services ( $h$ hours) and children's supply of care ( $h_{k}$ hours): 


$$
G=G\left(h, h_{k}\right)=e h+h_{k}
$$

where $e$ denotes the productivity of children's parental care of their parents.

Children cannot choose their work hours but can allocate the remaining hours, say 24 hours minus work hours, to leisure time $\left(l_{k}\right)$ and parental care $\left(h_{k}\right){ }^{2}$ Standardizing total feasible hours as one, the children's time constraint is:

$$
h_{k}=1-l_{k}
$$

At the same time, children decide whether to support their parents financially. The financial transfer to parents is denoted as $s_{k}$, and the budget constraint for children is:

$$
y_{k}=x_{k}+s_{k},
$$

where $x_{k}$ is the children's own consumption of goods and services.

Parents receive income $\left(y_{p}\right)$ and financial transfers from children $\left(s_{k}\right)$, and distribute them between the parents' own consumption $\left(x_{p}\right)$ and market care services $(h) .^{3}$ Designating the price of market long-term care services relative to private consumption as $p$, the parents' budget constraint is:

$$
s_{k}+y_{p}=x_{p}+p h
$$

The utility for children and for parents are respectively written as:

$$
\begin{aligned}
& U^{k}=U^{k}\left(x_{k}, l_{k}, G\right), \\
& U^{p}=U^{p}\left(x_{p}, G\right) .
\end{aligned}
$$

\footnotetext{
${ }^{2}$ The assumption of no work hours changes may be too strong although people cannot change work hours easily, at least in the short run. We use this assumption as our empirical investigation cannot control for labor decisions because of data limitations.

${ }^{3}$ Parents' income includes all kinds of money receipts (e.g., pension and dis-savings).
} 
The $G$ in utility is parents' health described as (1) and "family public goods". The utility including family public goods and the private goods of each household is often used in family-transfer models. In a framework of children-parent transfer, Cox (1987) and Ermisch (2003) denote this as “services” that children offer to their parents, and Pezzin and Schone (1999) denote this as “parents’ physical health or well-being”.

A family maximizes the following family welfare function subject to the constraints (2) (3), and (4):

$$
W=U^{k}+\mu U^{p},
$$

where $\mu$ is a parameter taking the value between zero and one. This is the "collective model” described by Chiappori (1992). The parameter, $\mu$, shows the weight of parents' utility relative to children's utility, which indicates the degree of altruism of children to their parents.

The first-order conditions of maximizing (7) subject to the constraints (2), (3), and (4), together give the following relationships:

$$
\begin{aligned}
\mu U_{x}^{p} & =U_{x}^{k}, \\
\mu U_{x}^{p} & =p^{-1}\left(U_{G}^{k}+\mu U_{G}^{P}\right), \text { and } \\
\left(U_{G}^{k}+\mu U_{G}^{P}\right) & =e^{-1} U_{l}^{k} .
\end{aligned}
$$

\footnotetext{
${ }^{4}$ The specification including "public family goods" of $G$ does not alter the test implications on altruism obtained from what follows. That is, even when the child does not get utility from the parent's health production, say $U^{k}=U^{k}\left(x_{k}, l_{k}\right)$, but when the family maximizes family utility (7) with the parent's utility (6), we obtain the exactly same comparative statics shown in Table 2.
} 
The subscript indicates the partial derivative, and we assume these are positive under normal assumptions $\left(U_{x}>0, U_{G}>0, U_{l}>0\right)$. The marginal utility of goods for children must be equal to the (weighted) marginal utility of good for parents, which must be equal to the sum of marginal utilities of long-term care production for children and parents evaluated at the relative price of health care. The sum of marginal utilities is further equal to the marginal utility of leisure for children discounted by their productivity.

Assume that $x, l$, and $G$ are additively separable in utility, the second derivatives of utility are negative $\left(U_{x x}<0, U_{l l}<0, U_{G G}<0\right)$, and the cross-derivatives are all zero. The second-order condition is that the bordered Hessian determinant is positive: $D=-e^{-1} U_{l l}^{k}\left(U_{G G}^{k}+\mu U_{G G}^{p}\right)\left(U_{x x}^{k}+\mu U_{x x}^{p}\right)-e \mu p^{2} U_{x x}^{k} U_{x x}^{p}\left\{\left(U_{G G}^{k}+\mu U_{G G}^{p}\right)+e^{-2} U_{l l}^{k}\right\}>0$.

Comparative statics show how parents' and children's income affect children's behaviors of money- and time-giving. First, the effect of parents' income on children's supply of parental care is written as:

$$
\frac{\partial h_{k}}{\partial y_{p}}=\frac{1}{D}\left\{p \mu U_{x x}^{k} U_{x x}^{p}\left(U_{G G}^{k}+\mu U_{G G}^{p}\right)\right\}<0 .
$$

Altruistic children supply more care to poorer parents. Likewise, the effect of parents' income on children's money transfers is written as:

$$
\frac{\partial s_{k}}{\partial y_{p}}=\frac{1}{D}\left\{e^{-1} U_{l l}^{k} U_{x x}^{p}\left(U_{G G}^{k}+\mu U_{G G}^{p}\right)\right\}<0 .
$$

Altruistic children give more money to poorer parents. In other words, non-altruistic children give more time or money as their parents become richer. For example, a child expecting an exchange for "presents” from the parent gives more parental care.

The effect of children's income on their money transfers to their parents is: 


$$
\frac{\partial s_{k}}{\partial y_{k}}=-\frac{1}{D} U_{x x}^{k}\left[e^{-1} U_{l l}^{k}\left(U_{G G}^{k}+\mu U_{G G}^{p}\right)+\mu p^{2} U_{x x}^{p}\left\{e^{-1} U_{l l}^{k}+e\left(U_{G G}^{k}+\mu U_{G G}^{p}\right)\right\}\right]>0 .
$$

The increase in children's income raises their own consumption, and accordingly their utility. For equalities to hold in the first-order conditions, children give more money to their parents and raise the parents' consumption of goods and long-term care services. Thus, the wealthier altruistic children would give more money to their parents.

In contrast, the effect of children's income on their parental care supply is:

$$
\frac{\partial h_{k}}{\partial y_{k}}=\frac{1}{D}\left\{p \mu U_{x x}^{k} U_{x x}^{p}\left(U_{G G}^{k}+\mu U_{G G}^{p}\right)\right\}<0 .
$$

This is exactly the same as (11). That is, as a child becomes richer, the family can afford to purchase more market care services to produce public goods of parental health, without sacrificing the children's leisure time (Indeed, $\left.\frac{\partial h}{\partial y_{k}}=\frac{1}{D}\left[-p \mu U_{x x}^{k} U_{x x}^{p}\left\{e\left(U_{G G}^{k}+\mu U_{G G}^{p}\right)+e^{-1} U_{l l}^{k}\right\}\right]>0\right)$. An increase in market care services and thus an increase in family public goods of parental health is met with an increase in children’s leisure time, which is a decrease in their parental care time.

Table 2 summarizes the test implications on altruism. Under altruism, the effects of the parents' income on children's time and money-giving are negative, and the effect of the children's income on the children's time-giving is negative but on money-giving is positive. Moreover, parents' income and children's income must affect the altruistic children's time-giving (nursing) in the same way. ${ }^{5}$

5 The obtained test implications are similar to those shown in past literature on exchange motives such as Cox and Rank (1992), Cox and Stark (1995), Pezzin and Schone (1997), Sloan et al. (1996, 97), where exchange motive shows a positive relationship between 


\section{Econometric Model of Parental Care}

Children's decisions about nursing and financial support may depend on each other. This does not change theoretical implications derived in the last section where individual's optimization problem is solved simultaneously for two decisions. This matters, however, in the empirical investigation. The same individual makes two decisions, so that they are probably correlated with each other.

We account for this possibility by allowing the disturbances of the equations representing the two decisions to be correlated with each other. The decisions on nursing ( $h$ ) and money-transfer ( $s$ ) are described as follows:

$$
\begin{aligned}
& y^{j}=\mathbf{x} \boldsymbol{\beta}^{j}+\varepsilon^{j} \quad j=h, s \\
& \left\{\begin{array}{l}
y^{j}=1 \text { if } y^{j *}>0 \text { and } \\
y^{j}=0 \text { otherwise } \\
\\
E\left(\varepsilon^{h}\right)=E\left(\varepsilon^{s}\right)=0 \\
\text { where } \quad \operatorname{Var}\left(\varepsilon^{h}\right)=\operatorname{Var}\left(\varepsilon^{s}\right)=1 . \\
\operatorname{Cov}\left(\varepsilon^{h}, \varepsilon^{s}\right)=\rho
\end{array}\right.
\end{aligned}
$$

We drop a subscript $k$ in the theory, since nursing and money-transfer are both children's decisions. Assume that the probability of both nursing and money-transfer, which is $\operatorname{Pr} o b\left(y^{h}=1, y^{s}=1 \mid \mathbf{x} ; \boldsymbol{\beta}^{h}, \boldsymbol{\beta}^{s}, \rho\right)=\Phi$, has a bivariate normal cumulative distribution

parent's richness and child's care-giving. The implications are different from those of mutual altruism, which generates income pooling (risk sharing) in households within extended families. In this case, transfers are unaffected by financial situation either of parents or children, once one controls for the overall extended family economic situation. 
function with mean $[0,0]$. We estimate these two equations by using a bivariate probit model. The log likelihood is the summation of $\Phi$ over individuals: $\ln L=\sum_{i=1}^{n} \ln \Phi\left(w_{i}^{h}, w_{i}^{s}, \rho_{i}^{*}\right)$, where $n$ is a total number of individuals, $w_{i}^{j}=q_{i}^{j} \cdot t_{i}^{j}$, $q_{i}^{j}=2 y_{i}^{j}-1, t_{i}^{j}=\mathbf{x}_{i} \boldsymbol{\beta}^{j}, \rho_{i}^{*}=q_{i}^{h} \cdot q_{i}^{s} \cdot \rho, q_{i}^{j}=1$ if $y^{j}=1$, and $q_{i}^{j}=-1$ if $y^{j}=0$.

The explanatory variables, $\mathbf{x}$, include parent's and children's economic situations. If altruism from children toward their parents exists, we will find the same four signs as shown in Table 2.

The most frequently calculated marginal effect is the unconditional marginal effect on choosing both nursing and money-transfer, which is $\partial \Phi / \partial \mathbf{X}=\sum g^{j} \boldsymbol{\beta}^{j}$, where $g^{h}=\sum_{i}^{n} \phi\left(w_{i}^{h}\right) \cdot \Phi\left[\frac{w_{i}^{s}-\rho_{i}^{*} w_{i}^{h}}{\sqrt{1-\rho_{i}^{* 2}}}\right]$ and $g^{s}=\sum_{i}^{n} \phi\left(w_{i}^{s}\right) \cdot \Phi\left[\frac{w_{i}^{h}-\rho_{i}^{*} w_{i}^{s}}{\sqrt{1-\rho_{i}^{* 2}}}\right]$. Note, however, that children do not have to offer both physical and financial support. Some children may use their own time to care for their parents, while others may offer substantial financial help. Hence, rather than compute the unconditional marginal effect, we calculate the marginal effects on choosing either nursing or financial support (assuming that the other type of support is not offered). These effects are $\partial E\left[y^{h}=1, y^{s}=0 \mid \mathbf{x}\right] / \partial \mathbf{x}$ and $\partial E\left[y^{h}=0, y^{s}=1 \mid \mathbf{x}\right] / \partial \mathbf{x}$. In addition, we calculate the conditional marginal effects on one form of support when the other form of support is given. These effects are $\partial E\left[y^{h} \mid y^{s}=1, \mathbf{x}\right] / \partial \mathbf{x}$ and $\partial E\left[y^{s} \mid y^{h}=1, \mathbf{x}\right] / \partial \mathbf{x}$.

If the error terms of the two equations for $h$ and $s$ are unrelated, in which case, $\rho=0$, we can simply calculate the unconditional marginal effects on each form of support. In this case, we can estimate an ordinal qualitative response model such as a probit or logit 
model for nursing and money-giving independently, rather than a bivariate probit model. Hence, we first estimate the two equations using a bivariate probit model and test whether the error terms are correlated. If they are not correlated, we calculate the unconditional marginal effects. If they are correlated, we calculate the conditional marginal effects described above.

\section{The Present Situation of the Japanese Elderly}

The Family Income and Expenditure Survey (FIES, conducted by the Statistics Bureau, Management and Coordination Agency) reports money transfers within Japanese families by type of income source, and includes workers, those in agriculture and fisheries, the self-employed, pensioners, the unemployed, and the independent elderly. According to the 1999 FIES, people receive money decreasingly as they age, but do so increasingly once they reach 60 (Figure 1-A). People give money increasingly once they reach 40, peaking at 50 years of age (Figure 1-B). The figure excludes money transfers to students within families and so mainly indicates financial help for dependent adults. The figures show that children care for their parents financially when the parents retire.

The transfer of time is also important within families. Table 1 shows the age of care-givers and care-receivers based on the CSLC of 2001. Care-giving increases among people in their fifties. Seventy-year olds are cared for by carers in the same age group. By contrast, eighty- and ninety-year olds are cared for by carers in their fifties or sixties. This suggests that spouses are the prime candidates for care giving, followed by children or a child's spouse. In addition, most carers are female, which indicates that informal care is primarily the work of wives, daughters, or daughters-in-law. The same report shows that 
$19.9 \%$ of carers are adult children, $22.5 \%$ are the adult children's spouses, and $25.9 \%$ are spouses.

The Survey on Time Use and Leisure Activities conducted by the Statistics Bureau, Management and Coordination Agency, reports that the average time spent being cared for is 95 minutes per day for females and 45 minutes for males in 2001. Note, however, that the average hours are misleading as care hours range widely depending on ADLs. According to 2001 CSLC, 37.9\% of the elderly need less than two hours help per day, $10 \%$ need 2-3 hours, $10 \%$ need half a day, and $27.4 \%$ need care almost all day long.

As an internationally pioneering policy, Japan’s public long-term care insurance was introduced in April 2000. One of the main purposes of this public mandatory insurance is to keep down the increased financial cost of caring for the elderly in an aging society, by reducing the number of elderly staying in hospitals for an excessively long time and by encouraging informal family care at home with home-help services. Generally, institutional care costs more than home care. The purchase of home help services is largely covered (10\% co-payment) by the new insurance. The new insurance policy may have affected the utilization of formal care and offers of family care. The results we show in this paper, which utilizes the survey conducted in fall 2000, reflect the situation after the implementation of the new public insurance.

\section{Data}

\section{A. The data}

The present paper uses The Attitude Survey on Childbirth, Child Care and Long-term Care for Parents (hereafter, ASCCL) conducted in October and November 2000. The 
survey asks married women aged between 20 and 49 about childcare and parental care in the past, present, and future. Not only are carers surveyed, but independent members of their families are also surveyed. ${ }^{6}$

The main advantage of using these data for our analysis is that the survey asks children about caring in the future for parents who currently do not need long-term care. When only current care is asked about, insufficiently large samples of those in need of long-term care are obtained, because there are a limited number of such people in the country. Because the ASCCL asks about the possibility of future care, it provides sufficient observations for an empirical investigation. Although a plan may not show an actual outcome, this does not defeat the purpose of our study, which is to analyze children's willingness to take care of their parents.

In addition, the question about the possibility of future care partially solves the endogeneity problem of living arrangements, which in previous papers was found to affect results. That is, we can analyze the outcomes (future behavior) while treating the current situation as given. As do theoretical models, we focus on the behavior of children living separately from their parents. We cannot distinguish between the cause and effect of family formation and various decisions on long-term care if we included the intention

\footnotetext{
${ }^{6}$ More specifically, the data are obtained from a study on the aging society, directed by Professor Tachibanaki of Kyoto University, as one of the New Millennium Projects of the Economics and Social Research Institute, at the Cabinet Office. The respondents are randomly chosen through a two-step stratified method. Of the 5,000 questionnaires distributed, 1,493 (29.9\%) replies were obtained.
} 
of dependent children, who may co-reside, to provide future long-term care.

Like all sample surveys, however, the ASCCL has the disadvantage of being a limited selected sample. We checked that the ASCCL sample was not biased by comparing it with other large samples of well-known Japanese data, the Employment Status Survey (Shugyo-Kozo-Kihon-Chosa) conducted by the Statistic Bureau, Management and Coordination Agency in 1997. We limit the whole sample of the Employment Status Survey to the same age group as that in the ASCCL for the purpose of comparison. According to the Appendix Table, the ASCCL sample distribution is very similar to that of the Employment Status Survey, although the educational attainment of ASCCL respondents, who are daughters or daughters-in-law, and their total household incomes, are slightly higher than those reported in the Employment Status Survey. In addition, there are more social and welfare worker respondents in the ASCCL, which may cause the results to favor altruism.

\section{B. The variables}

The ASCCL examines the characteristics and situations of the adult child's (respondent's) family and living parents; both the wife's and the husband's, and each mother and father, separately. The survey asks children what they would do for each parent, not yet in need of long-term care, if that parent needed long-term care. We treat parents' answers as different observations, and the total sample to be analyzed thus equals the number of living parents who are not yet in need of care.

With regard to future informal care, the survey asks, "What would you do if your parent needed long-term care?” The possible responses are: (1) care at home; (2) care in an institution; (3) give money; (4) buy formal care services; and (5) do not know. More 
than one answer could be chosen. We define a binary dummy variable for the child's care provision, which takes the value of unity if (1) is chosen. Similarly, a binary dummy recording money-transfer takes the value of unity when (3) is chosen.

Important explanatory variables are the economic situations of the parents and the children. For the parents, we use information on educational attainment and pension received. Educational attainment indicates not only the current economic situation but also past and future economic situations; that is, life-cycle income and assets. A strongly positive relationship between educational attainment and lifetime income or assets is found in abundant previous literature in Japan. ${ }^{7}$

In the estimation, the father's number of years of education is treated as the parents' household education level. This is because the father is the main income earner, particularly among Japanese who were elderly at the time of the survey. However, the estimation results did not change with other specifications of the education variable.

Pension received signals a parent's present economic situation. Because Japanese people receive at least the basic pension according to the mandatory pension system, we distinguish between those receiving only the basic pension and those receiving the basic pension plus other pensions. If the parent is in the latter group, a dummy variable for 'basic plus other pensions' takes the value of unity. For parents who have not yet retired,

\footnotetext{
${ }^{7}$ For example, Kasuga (2000) reports that the income and asset holdings of the elderly are positively related to their educational attainment, using a large set of cross-sectional data for Japanese households. Tachibanaki and Tanigawa (1990) show that college graduates are more likely than non-graduates to hold financial assets.
} 
the child was asked to report any future pension that the parent might receive.

The children's economic situation is recorded using the husband's labor income, household asset holdings, and borrowings. The husband's labor income is the previous year's annual labor income taking 11-category from zero to more than 30 million yen. Instead of using the husband's income, we can use annual family total income, which is also category data. Choice of either income specification does not alter the main results.

To control for carer characteristics, we use the wife's labor status. Full-time worker and part-time worker dummies are included and compared to non-working wives. In addition, educational attainment and age, the number of children, and the eldest child's age are controlled for. ${ }^{8}$ The carer's residential area also affects behavior. We expected a difference between metropolitan areas and others, using two dummy variables indicating cities and villages, with metropolitan cities designated by ordinance being the base case. To control for home ownership, we include dummy variables indicating whether a house is owned by children, children and parents, or other family members, and one for a rented house, with the base case being home ownership by parents. Children living in their

\footnotetext{
${ }^{8}$ The existence of the adult children's children (grandchildren) is used to test for the demonstration effect shown in Cox and Stark (1995). However, this framework cannot distinguish the demonstration effect from a time constraint on home production: the existence of grandchildren indicates more time constraints on the wife's home production (and accordingly less time for parental care) as well as a greater demonstration effect (and accordingly more time for parental care). In this paper, we use the grandchildren and their ages simply as control variables.
} 
parents' house but separately from the parents might already have received benefits from the parents; in exchange for this, those children may offer more care time and/or money to their parents.

For parents, whether or not they are a couple can make a difference. We control for this by using a dummy variable indicating that a parent has a spouse. Moreover, we differentiate between the wife's parents and the husband's. Japanese tradition dictates that the wife should take care of her husband's parents. As Oishi and Oshio (2001) explain, this may place a huge burden on carers, thereby invading their privacy. If the burden is onerous for children, they may not provide informal family care. We can analyze the differential burdens borne by care-givers using a dummy variable for the wife’s parent.

The descriptive statistics are shown in Table 3. As mentioned, we restrict the sample to independent children (living separately from their parents) in order to avoid the endogeneity problem of children's decisions about co-residence and money and time transfer. We exclude single people and those whose parents are deceased. ${ }^{9}$ The sample size used for estimation is 872 .

Before examining the estimation results, we provide a general overview of the data used. Panel A of Figure 2 summarizes the living arrangements of the sample at the time of the survey. Cases in which the parents live with the respondent (children) or other family members account for $51.79 \%$ (14.18 plus 37.61$)$ of the total. The proportion of parents living in institutions is $0.27 \%$. Panel 2 of Figure 2 summarizes what would happen if the

\footnotetext{
${ }^{9}$ It is possible that altruism is biased downwards in our estimation because we restrict the sample to independent married children.
} 
parent needed long-term care. A significant proportion of children intend to offer informal care: about 14\% of parents living at institutions, 34\% living with spouse, 35\% living with other family members, and 36\% living alone (on average, about $30 \%$ of those residing separately) would be cared by their children.

There are many “don’t knows” in the sample. Their characteristics are that parents and respondents are still young, the husband's income is low, and the wife is not working. We exclude those responding “don’t know" from the estimated samples, assuming that these respondents cannot decide their intentions regarding the provision of future care.

\section{Estimation Results}

The estimation results are summarized in Table 4. The error terms of the two estimating equations for nursing and money-giving are negatively correlated at the $1 \%$ significance level, which supports the use of the bivariate probit model. ${ }^{10}$

The marginal effects from the estimation results in Table 4 are then calculated. First, column (1) in Table 5-A reports the marginal effects of money-giving without nursing. The coefficient on children's income is significantly positive, and the coefficient on extra pension is significantly negative at the $1 \%$ level. The coefficient on parents' educational attainment is insignificant but negative. The signs are the same as those shown in the left column in Table 2.

\footnotetext{
${ }^{10}$ Since parents' educational attainment may be positively related to their pension benefits, we also estimate after dropping 'basic plus other pensions'. We obtained the same implications of the main variables indicating children's and parents’ wealth.
} 
Column (2) in Table 5-A shows marginal effects for nursing without money-giving. The children's income reduces nursing by children when they are not giving money. This effect is significant at the $1 \%$ level. In contrast, the parents' educational attainment has a positive effect on nursing by children, which is significant at the $5 \%$ level. Larger pension benefits (that is, larger than the basic pension) have an insignificant but positive effect on nursing by children. Thus, children offer more nursing time to wealthier parents. This implies a lack of altruism. If Japanese children were altruistic, we would have found the same signs as those summarized in Table 2. The overall result rejects altruism.

With regard to other significant variables, working wives, especially those working full time, give less time and more money to parents than do non-working wives. Children give more time and less money to older parents, and more money to the wife's parents. In addition, children living in metropolitan cities give more money to parents, which may indicate some physical difficulty in parental care by children who live separately from parents living in rural places.

With regard to the variables on home ownership, children owning their own houses give less money to the parents, compared to the base case of home ownership by parents. In other words, children living in a house owned by their parents (but separately from their parents) give more money to their parents. Although this looks like the outcome of mutual altruism, it also implies the possibility of an exchange motive. That is, children provide more care for their parents when they receive benefits from their parents in the form of housing.

Table 5-B reports the second type of marginal effects. Columns (1) and (2) report the marginal effects for money-giving in addition to nursing and those for nursing in addition 
to money-giving, respectively. The implications of the results are the same as those for the results in Table 5-A: children's income has a negative effect on nursing and a positive effect on money transfers. Parents' educational attainments have a significantly positive effect on nursing, but an insignificant effect on financial support. The overall result suggests no altruism. The effects of the other significant explanatory variables are similar to those of the variables in Table 5-A and somewhat reinforce the finding that children living in a house owned by their parents provide more nursing and give more money.

We make several comments on the interpretation of the above results. First, there is a possibility that the answer is just a plan but would not be an actual action when the need for parental care actually occurred. This does not nullify the results we obtained. We dropped “don’t know” samples, who are not sure about future plan for parental care. More fundamentally, our objective is to analyze children's willingness, and respondent's intentions are good enough to be examined.

Secondly, the variable of parents' educational attainment may indicate not parents' lifetime wealth and income but other family characteristics, although much of the existing literature suggests a strong relationship between educational attainment and lifetime wealth in Japan (see footnote 6). For example, parents' higher educational attainment may reflect a smaller number of children in a family. In this case, each child would have a greater burden of parental care either in a monetary or time sense, and would need to offer parental care. However, the statistics do not show a negative correlation between parents’ educational attainment and the number of children. According to the Japanese Panel Survey of Consumption, which is the unique panel data on Japanese households, conducted by the Institute for Research on Household Economics, the average numbers 
of children with a father with 9, 12, 14, and over 16 years of education are 2.45, 2.44, 2.00, 2.50, and 2.52, respectively. With respect to the mother's years of education, these numbers are $2.43,2.42,2.42$, and 2.75 , respectively.

As another possibility, parents with higher education may instill the importance of family ties, and the child in such families may care for parents more. This might be true, but it does not explain the differential in the sign of parental education between money-transfer and time-transfer: why does the child of a parent with higher education offer less nursing although he/she offers more financial support?

We can conclude that parental care, especially nursing of parents, by Japanese children is not motivated by altruism. If devoting time is a more positive action than giving money, non-altruistic motives inspire children to care for their parents. Furthermore, the results of this paper apply when parents face the inevitable negative shock of needing long-term care. Even in the case of ill parents, no evidence of family altruistic behavior is found.

Japanese children do not appear to be motivated by altruism. This tendency could be growing, as our results suggest, when more wives work full time. According to the Employment Status Survey (Shugyo-Kozo-Kihon-Chosa), the percentage of full-time workers among them increased from $62.4 \%$ in 1987 to $67.4 \%$ in 1997 . If this tendency continues, informal care supplied by children will steadily decrease.

\section{Conclusion}

This paper has analyzed informal care and money-giving by children to their frail elderly parents. We first showed the theoretical model of altruistic children's time and money transfers to their parents. The comparative statics revealed implications of 
altruism in the form of children's caring for their frail parents.

Our empirical investigation used data from the unique survey, "The Attitude Survey on Child-care and Long-term Care of the Parents”, conducted by the Cabinet Office of the Japanese Government in 2000. The survey asked children about their future plans for financial support and/or parental care in the event that their parents became ill and needed long-term care. This made it possible for us to solve the endogeneity problem relating to children's parental care and other economic decisions: we were able to examine children's decisions about future parental care, holding the present situation as given.

According to the survey, about $30 \%$ of children living separately from their parents provide parental care when the parents need it. Further investigation, however, shows that this parental care is not motivated by altruism. That is, children give parental care when their parents are sufficiently wealthy to enable the children to meet their parents' care needs. This tendency will increase as more daughters (and daughters-in-law) join the full-time workforce.

Although the evidence against altruism is rather weak in terms of money-giving, the overall evidence against altruism remains strong. We should note that giving time is a more positive form of care than giving money, and that altruistic care of parents is not supported even when parents are physically ill and need help.

The results suggest that we should not rely too much on altruism within families. Declining family care should be replaced by market care services. This is supported by our results: as dual-income child-couples increase, they are able to give more money to their frail elderly parents. A potentially large demand for market care services exists and will possibly increase in the future. 


\section{References}

Ando, A., Yamashita, M., Murayama, J., 1986. Lifecycle Kasetsu ni Motozuku Shouhi Chochiku no Bunseki. The Economic Analysis 101, 25-114, (in Japanese).

Bernheim, B.D., Shleifer, A., Summers, L., 1985. The Strategic Bequest Motive. Journal of Political Economy 93, 1045-176.

Chiappori, P., 1992. Collective Labor Supply and Welfare. The Journal of Political Economy 100, 437-67.

Cox, D., 1987. Motives for Private Income Transfers. Journal of Political Economy 95, 508-46.

Cox, D., Rank, M., 1992. Inter Vivos Transfers and Intergenerational Exchange. Review of Economics and Statistics 74, 305-14.

Cox, D., Stark, O., 1995. An Exchange Implication of Transfers: The Demonstration Effect. In: Stark, O. (Ed.), Altruism and Beyond: An Economic Analysis of Transfers and Exchanges within Families and Groups (Oscar Morgenstern Memorial Lectures). Cambridge University Press, Cambridge, pp. 48-85.

Ermisch, J., 2003. An Economic Analysis of the Family. Princeton University Press, Princeton.

Hayashi, F., 1995. Is the Japanese Extended Family Altruistically Linked? A Test Based on Engel Curves. Journal of Political Economy 103, 661-74.

Iwamoto, Y., Fukui, T., 2001. Doukyo Sentaku niokeru Shotoku no Eikyo. Japan Center for Economic Research Economic Journal 42, 21-43, (in Japanese).

Kasuga, N., 2000. Kakei ni okeru Kinyu Shisan Sentaku ni kansuru Chosa (vol.6) no 
Bunseki. Mimeo, (in Japanese).

Komamura, K., 1994. Koureisha Kakei ni okeru Isan Koudou no Keizai Bunseki. The Quartery of Social Security Research 30, 62-74, (in Japanese).

Ohtake, F., 1991. Bequest Motives of Aged Households in Japan. Ricerche Economiche 45, 283-306.

Ohtake, F., Horioka, C. Y., 1994. Chochiku Douki. In: Ishikawa, T. (Ed.), Nihon no Shotoku to Tomi no Bunpai. The University of Tokyo Press, Tokyo, pp. 211-44, (in Japanese).

Oishi, A., Oshio, T., 2001. Doukyo Sentaku to Tsuma no Shugyo Kettei: Dochira no Oya to Doukyo Surunoka?. National Institute of Population and Social Security Research Working Paper Series (J) \#4, (in Japanese).

Pezzin, L., Schone, B., 1997. The Allocation of Resources in Intergenerational Households: Adult Children and Their Elderly Parents. American Economic Review $87,460-4$.

Pezzin, L., Schone, B., 1999. Intergenerational Household Formation, Female Labor Supply and Informal Caregiving: A Bargaining Approach. Journal of Human Resources 34, 475-503.

Schoeni, R., 1997. Private Interhousehold Transfers of Money and Time: New Empirical Evidence. The Review of Income and Wealth 43, 423-448.

Sloan, F., Hoerger, T., Picone, G., 1996. Public Subsidies, Private Provision of Care and Living Arrangements of the Elderly. Review of Economics and Statistics 78, $428-440$.

Sloan, F., Picone, G., Hoerger, T., 1997. The Supply of Children’s Time to Disabled 
Elderly Parents. Economic Inquiry 35, 295-308.

Tachibanaki, T., Tanigawa, Y., 1990. Households' Portfolio Behavior: An Econometric Analysis on the Portfolio Pattern in Japan. Finance Kenkyu, (in Japanese).

Takayama, N., Arita, F., 1996. Chochiku to Shisan Keisei: Kakei Shisan no Macrodata Bunseki, Iwanami, Tokyo, (in Japanese).

Yashiro, N., 1993. Koureisha Setai no Keizaiteki Chii. Japan Center for Economic Research Economic Journal 25, 34-57, (in Japanese). 

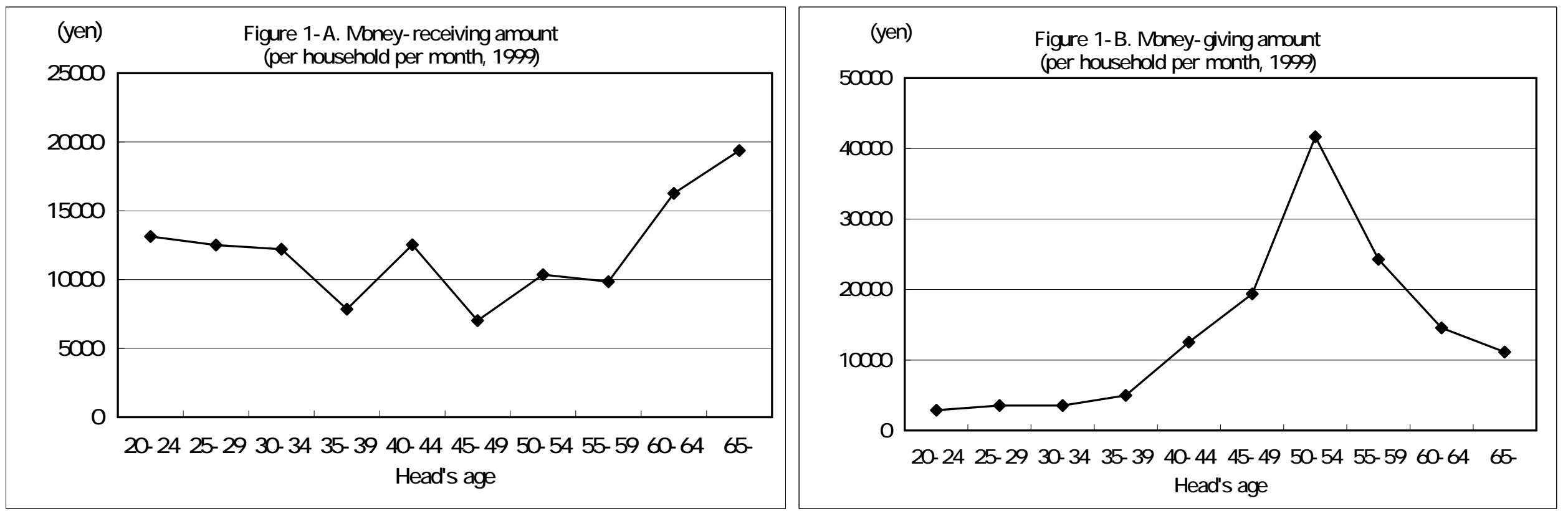

Notes. 1) Compiled from the Family Income and Expenditure Survey in 1999.

2) The figure excludes transfers to students in a family.

Table 1. Gender and Ages of informal caregiver and carereceiver

\begin{tabular}{|c|c|c|c|c|c|c|c|c|}
\hline & \multicolumn{7}{|c|}{ Age of Carereceiver (\%) } \\
\hline & & All & age $40-64$ & $65-69$ & 70- 79 & $80-89$ & age over 90 & $\begin{array}{l}\text { (summary) } \\
\text { age over } 65\end{array}$ \\
\hline \multirow{9}{*}{ Family Caregiver } & All [\% all ages] & {$[100.0 \%$} & $5.8 \%$ & {$[7.2 \%$} & $28.8 \%$ & {$[41.9 \%$} & $16.4 \%$ & $94.2 \%$ \\
\hline & Male & 23.6 & 35.5 & 28.6 & 29.6 & 20.0 & 16.1 & 22.9 \\
\hline & Female & 76.4 & 64.5 & 71.4 & 70.4 & 80 & 83.9 & 77.1 \\
\hline & - age40 & 4.2 & 12.3 & 12.7 & 4.0 & 1.8 & 4.4 & 3.8 \\
\hline & age $40-49$ & 12.7 & 9.7 & 7.8 & 19.3 & 13.4 & 2.6 & 12.9 \\
\hline & $50-59$ & 29.4 & 33.1 & 8.8 & 18.1 & 42.6 & 23.4 & 29.2 \\
\hline & $60-69$ & 26.0 & 33.1 & 53.7 & 13.0 & 18.9 & 52.5 & 25.6 \\
\hline & $70-79$ & 21.5 & 9.5 & 17.0 & 39.8 & 14.0 & 14.4 & 22.2 \\
\hline & age over 80 & 6.2 & 2.4 & & 5.9 & 9.2 & 2.7 & 6.4 \\
\hline
\end{tabular}

Note. 1) Source: the Comprehensive Survey of Living Conditions of the People on Health and Welfare (CSLC), reported by the Ministry of Health and Welfare in 2001. 
Table 2. The effects of income on altruistic children' s time and money transfers

\begin{tabular}{|c|c|c|}
\hline & \multicolumn{2}{|c|}{ Transfers from Children to the Parents } \\
& Financial support $\left(\mathrm{s}_{\mathrm{k}}\right)$ & Nursing $\left(\mathrm{h}_{\mathrm{k}}\right)$ \\
\hline Parent's Income $(\mathrm{Yp})$ & - & - \\
\hline Child's Income $(\mathrm{Yk})$ & + & - \\
\hline
\end{tabular}


Table 3. Descriptive Statistics of "Attitude Survey on Long- term Care"(2000)

\begin{tabular}{|c|c|c|c|c|c|}
\hline \multirow{2}{*}{\multicolumn{2}{|c|}{872 observations }} & \multicolumn{3}{|c|}{ standard } & \multirow[b]{2}{*}{ maxmium } \\
\hline & & mean & deviation & minimum & \\
\hline \multicolumn{2}{|c|}{ Time Transfers (Nursing) \% } & 0.3452 & 0.4757 & 0 & 1 \\
\hline \multicolumn{2}{|c|}{ Money Transfers \% } & 0.3245 & 0.4685 & 0 & 1 \\
\hline \multirow[t]{6}{*}{ Parent } & education & 12.1583 & 2.6018 & 9 & 16 \\
\hline & basic plus other pensions & 0.6881 & 0.4635 & 0 & 1 \\
\hline & age & 66.5080 & 7.2980 & 40 & 88 \\
\hline & gender & 0.4989 & 0.5003 & 0 & 1 \\
\hline & wife's parents & 0.4966 & 0.5003 & 0 & 1 \\
\hline & no spouse & 0.0390 & 0.1937 & 0 & 1 \\
\hline \multirow[t]{15}{*}{ Kid } & husband's labor income \# & 7.4209 & 1.7193 & 1 & 11 \\
\hline & wife's working: part- time & 0.3670 & 0.4823 & 0 & 1 \\
\hline & wife's working: full- time & 0.1651 & 0.3715 & 0 & 1 \\
\hline & wife's education & 13.6032 & 1.6082 & 9 & 16 \\
\hline & wife's age & 37.0917 & 6.3630 & 21 & 49 \\
\hline & child(ren) & 0.8716 & 0.3348 & 0 & 1 \\
\hline & eldest child's age & 8.9358 & 7.1642 & 0 & 27 \\
\hline & debt \# & 4.4518 & 3.2048 & 1 & 10 \\
\hline & asset income \# & 3.9518 & 2.0023 & 1 & 10 \\
\hline & homeowner 1 (children) & 0.5034 & 0.5003 & 0 & 1 \\
\hline & homeowner 2 (children and parents) & 0.0333 & 0.1794 & 0 & 1 \\
\hline & homeowner 3 (other family members) & 0.0138 & 0.1166 & 0 & 1 \\
\hline & rental house & 0.3865 & 0.4872 & 0 & 1 \\
\hline & residential area (city) & 0.5986 & 0.4905 & 0 & 1 \\
\hline & residential area (villages) & 0.1021 & 0.3029 & 0 & 1 \\
\hline
\end{tabular}

Notes. 1) The variable with \# shows category data. Labor income is anual value in yen, $1>$ none, $2>$ less than 500,000 , $3>500,000$ 1million, $4>2 \mathrm{~m}, 5>3 \mathrm{~m}, 6>4 \mathrm{~m}, 7>6 \mathrm{~m}, 8>8 \mathrm{~m}, 9>10 \mathrm{~m}, 10>15 \mathrm{~m}, 11>20 \mathrm{~m}, 12>25 \mathrm{~m}, 13>30 \mathrm{~m}$, $14>$ over 30million. As for debt and asset income, 1>none, 2>less than 1million, $2>3 \mathrm{~m}, 4>5 \mathrm{~m}, 5>7 \mathrm{~m}, 6>10 \mathrm{~m}$, $7>15 \mathrm{~m}, 8>30 \mathrm{~m}, 9>50 \mathrm{~m}, 10>100 \mathrm{~m}, 11>120 \mathrm{~m}, 12>$ more than 120 million.

2) Parent's education is the number of years of education the father attained.

3) 'Basic plus other pensions' takes one if parents (can) get any pension in addition to the basic one after retirement.

4) Homeowner 1, 2 and 3 indicate the owners are children, children and parents, and other family members, respectively. 
Figure 2. What will children do when their parent needed long- term care?

Panel A. The present living arrangements of parents, \% of 4084 elderly parents

live separately from their adult live together

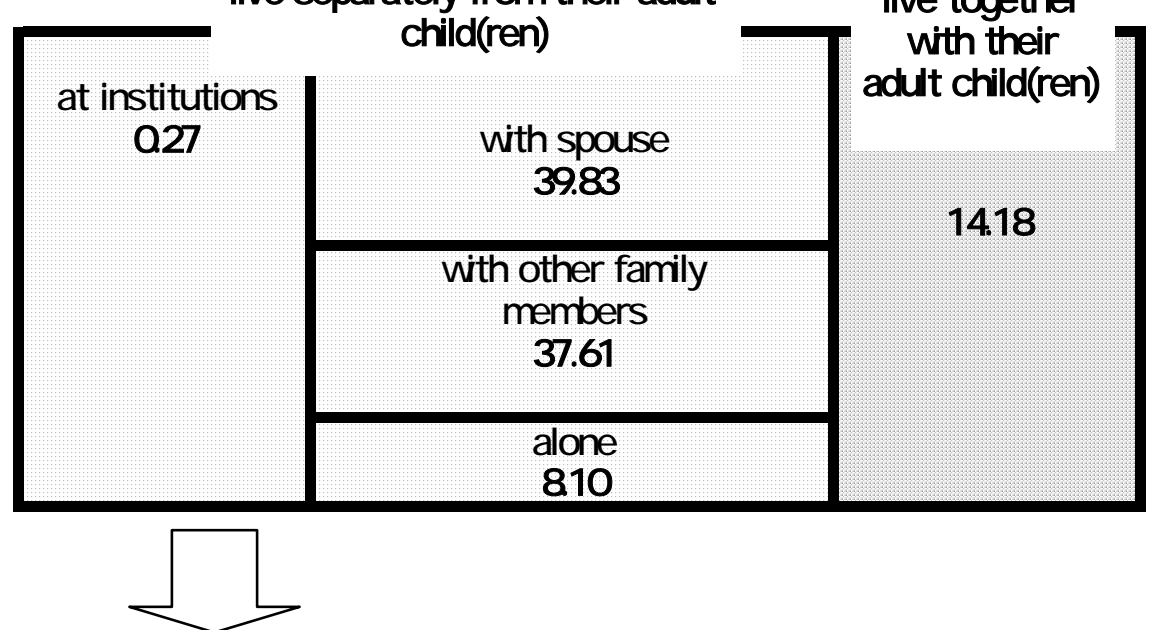

Panel B. When the parent needed long- term care,

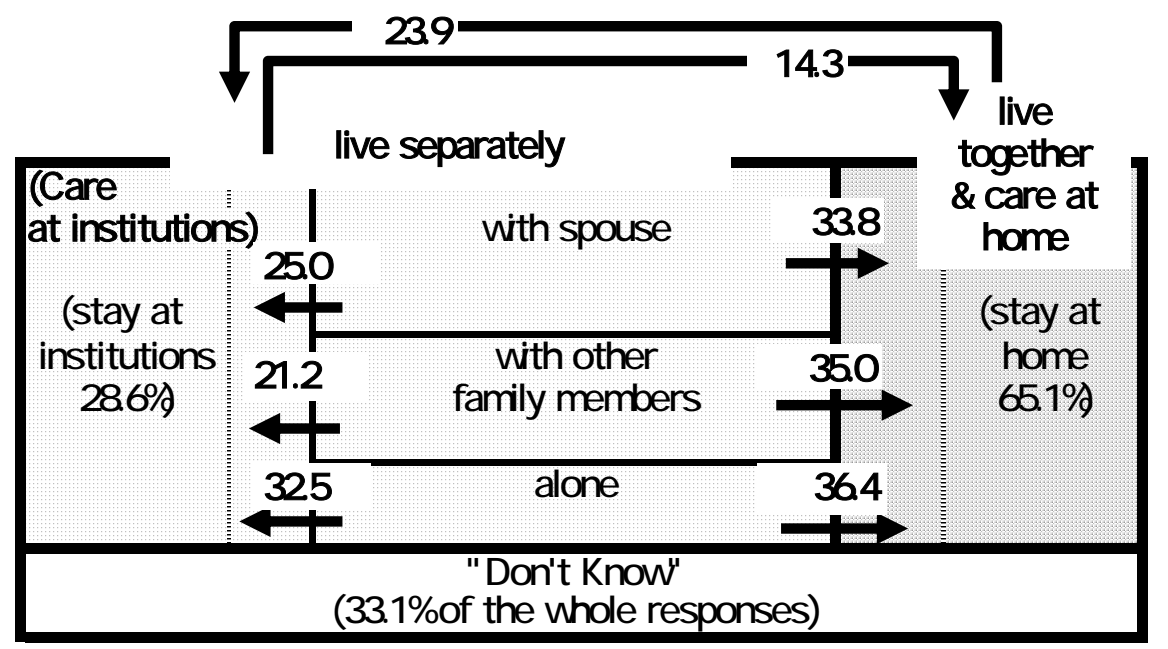

Note. The number above an arrow in Panel B shows \% of moving out from each box. 
Table 5. Calculated Conditional Marginal Effects (CME) on Children's Money and Time Transfers to the Parents based on the results in Table4.

\begin{tabular}{|c|c|c|c|c|}
\hline \multirow[t]{2}{*}{ Parent } & \multicolumn{2}{|c|}{$\begin{array}{l}\text { A. } \\
\text { CME on providing one form of support in } \\
\text { cases of not providing the other supoort } \\
\begin{array}{c}\text { (1)Financial support } \\
\text { without nursing }\end{array} \quad \text { (2) Nursing without } \\
\text { financial support }\end{array}$} & \multicolumn{2}{|c|}{$\begin{array}{l}\text { B. } \\
\text { CME providing one form of support in cases } \\
\text { of providing the other support } \\
\text { (1)Financial support } \\
\text { in addition to nursing to financial support }\end{array}$} \\
\hline & & & & \\
\hline education & $\begin{array}{l}-0.0064 \\
(0.0056)\end{array}$ & $\begin{array}{c}0.0114 * * \\
(0.0059)\end{array}$ & $\begin{array}{l}-0.0013 \\
(0.0064)\end{array}$ & $\begin{array}{c}0.0125 * \\
(0.0066)\end{array}$ \\
\hline basic plus other pensions & $\begin{array}{l}-0.0748 * * * \\
(0.0291)\end{array}$ & $\begin{array}{r}0.0202 \\
(0.0285)\end{array}$ & $\begin{array}{l}-0.1107 * * * \\
(0.0340)\end{array}$ & $\begin{array}{l}-0.0369 \\
(0.0335)\end{array}$ \\
\hline age & $\begin{array}{l}-0.0059 * * \\
(0.0030)\end{array}$ & $\begin{array}{l}0.0086 * * * \\
(0.0031)\end{array}$ & $\begin{array}{l}-0.0027 \\
(0.0035)\end{array}$ & $\begin{array}{l}0.0085 * * \\
(0.0035)\end{array}$ \\
\hline gender & $\begin{array}{r}0.0140 \\
(0.0270)\end{array}$ & $\begin{array}{l}-0.0302 \\
(0.0283)\end{array}$ & $\begin{array}{r}-0.0012 \\
(0.0307)\end{array}$ & $\begin{array}{l}-0.0358 \\
(0.0315)\end{array}$ \\
\hline wife's parents & $\begin{array}{c}0.0481 * \\
(0.0259)\end{array}$ & $\begin{array}{l}-0.0271 \\
(0.0272)\end{array}$ & $\begin{array}{c}0.0564 * \\
(0.0296)\end{array}$ & $\begin{array}{l}-0.0011 \\
(0.0303)\end{array}$ \\
\hline no spouse & $\begin{array}{l}-0.0815 \\
(0.0589)\end{array}$ & $\begin{array}{r}0.0135 \\
(0.0742)\end{array}$ & $\begin{array}{l}-0.1064 * \\
(0.0612)\end{array}$ & $\begin{array}{l}-0.0405 \\
(0.0721)\end{array}$ \\
\hline Kid & & & & \\
\hline husband's labor income & $\begin{array}{l}0.0379 * * * \\
(0.0104)\end{array}$ & $\begin{array}{l}-0.0281 * * * \\
(0.0105)\end{array}$ & $\begin{array}{l}0.0390 * * * \\
(0.0122)\end{array}$ & $\begin{array}{l}-0.0116 \\
(0.0117)\end{array}$ \\
\hline wife's working: parttime & $\begin{array}{l}0.1435 * * * \\
(0.0325)\end{array}$ & $\begin{array}{l}-0.1590 * * * \\
(0.0287)\end{array}$ & $\begin{array}{l}0.0945 * * * \\
(0.0375)\end{array}$ & $\begin{array}{l}-0.1386 * * * \\
(0.0339)\end{array}$ \\
\hline wife's working: fulltime & $\begin{array}{l}0.2687 * * * \\
(0.0483)\end{array}$ & $\begin{array}{l}-0.1875 * * * \\
(0.0282)\end{array}$ & $\begin{array}{l}0.2292 * * * \\
(0.0558)\end{array}$ & $\begin{array}{l}-0.1332 * * * \\
(0.0391)\end{array}$ \\
\hline wife's education & $\begin{array}{r}0.0081 \\
(0.0093)\end{array}$ & $\begin{array}{l}-0.0256 * * * \\
(0.0098)\end{array}$ & $\begin{array}{l}-0.0072 \\
(0.0106)\end{array}$ & $\begin{array}{l}-0.0336 * * * \\
(0.0109)\end{array}$ \\
\hline wife's age & $\begin{array}{r}0.0014 \\
(0.0045)\end{array}$ & $\begin{array}{l}-0.0051 \\
(0.0047)\end{array}$ & $\begin{array}{l}-0.0019 \\
(0.0051)\end{array}$ & $\begin{array}{l}-0.0070 \\
(0.0052)\end{array}$ \\
\hline child(ren) & $\begin{array}{r}0.0574 \\
(0.0414)\end{array}$ & $\begin{array}{l}-0.0905 * \\
(0.0543)\end{array}$ & $\begin{array}{r}0.0282 \\
(0.0509)\end{array}$ & $\begin{array}{l}-0.0890 \\
(0.0605)\end{array}$ \\
\hline eldest child's age & $\begin{array}{l}-0.0043 \\
(0.0037)\end{array}$ & $\begin{array}{r}0.0039 \\
(0.0038)\end{array}$ & $\begin{array}{l}-0.0038 \\
(0.0042)\end{array}$ & $\begin{array}{r}0.0025 \\
(0.0042)\end{array}$ \\
\hline debt & $\begin{array}{l}-0.0010 \\
(0.0065)\end{array}$ & $\begin{array}{r}0.0031 \\
(0.0068)\end{array}$ & $\begin{array}{r}0.0008 \\
(0.0074)\end{array}$ & $\begin{array}{r}0.0040 \\
(0.0076)\end{array}$ \\
\hline asset income & $\begin{array}{r}0.0104 \\
(0.0082)\end{array}$ & $\begin{array}{l}-0.0024 \\
(0.0086)\end{array}$ & $\begin{array}{r}0.0150 \\
(0.0093)\end{array}$ & $\begin{array}{r}0.0053 \\
(0.0096)\end{array}$ \\
\hline homeowner1 & $\begin{array}{l}-0.1136 * \\
(0.0599)\end{array}$ & $\begin{array}{l}-0.0385 \\
(0.0642)\end{array}$ & $\begin{array}{l}-0.2221 * * * \\
(0.0690)\end{array}$ & $\begin{array}{l}-0.1678 * * \\
(0.0725)\end{array}$ \\
\hline homeowner2 & $\begin{array}{l}-0.0976 \\
(0.0697)\end{array}$ & $\begin{array}{l}-0.0799 \\
(0.0814)\end{array}$ & $\begin{array}{l}-0.1497 * \\
(0.0589)\end{array}$ & $\begin{array}{l}-0.1426 * * \\
(0.0676)\end{array}$ \\
\hline homeowner3 & $\begin{array}{l}-0.1785 * * * \\
(0.0481)\end{array}$ & $\begin{array}{r}0.1321 \\
(0.1516)\end{array}$ & $\begin{array}{l}-0.1929 * * * \\
(0.0514)\end{array}$ & $\begin{array}{r}0.0143 \\
(0.1388)\end{array}$ \\
\hline rental house & $\begin{array}{l}-0.0668 \\
(0.0518)\end{array}$ & $\begin{array}{l}-0.0681 \\
(0.0552)\end{array}$ & $\begin{array}{l}-0.1490 * * * \\
(0.0558)\end{array}$ & $\begin{array}{l}-0.1533 * * * \\
(0.0587)\end{array}$ \\
\hline residential area:city & $\begin{array}{l}-0.0531 * \\
(0.0296)\end{array}$ & $\begin{array}{r}0.0092 \\
(0.0307)\end{array}$ & $\begin{array}{l}-0.0806 * * \\
(0.0339)\end{array}$ & $\begin{array}{l}-0.0331 \\
(0.0349)\end{array}$ \\
\hline residential area:village & $\begin{array}{l}-0.0861 \text { ** } \\
(0.0387)\end{array}$ & $\begin{array}{r}0.0873 \\
(0.0556) \\
\end{array}$ & $\begin{array}{l}-0.0805 * \\
(0.0456)\end{array}$ & $\begin{array}{r}0.0514 \\
(0.0591) \\
\end{array}$ \\
\hline $\begin{array}{l}\text { Probability of }(1) /(2) \text { given } \\
\text { all explanatory variables }\end{array}$ & 0.2292 & 0.2569 & 0.2393 & 0.2607 \\
\hline
\end{tabular}


Appendix Table. Comparison of 2000 Attitude Survey on Child- care and Long-term Care (ASCLC),

with large sample survey on J apanese labors: the 1997 Employment Status Survey (ESS)

\section{(1) educational attainments}

\begin{tabular}{|c|c|c|}
\hline & ASCLC & ESS \\
\hline $\begin{array}{ll}\text { wife } & \text { junior high school } \\
& \text { high school } \\
\text { two- year colleges } \\
\text { four- year universities }\end{array}$ & $\begin{array}{l}3.05 \\
44.53 \\
37.75 \\
14.66\end{array}$ & $\begin{array}{l}9.20 \\
56.41 \\
24.82 \\
9.56\end{array}$ \\
\hline $\begin{array}{l}\text { husband junior high school } \\
\text { high school } \\
\text { two- year colleges } \\
\text { four- year universities }\end{array}$ & $\begin{array}{l}6.22 \\
39.14 \\
12.64 \\
42.01\end{array}$ & $\begin{array}{c}11.07 \\
48.52 \\
7.79 \\
32.62\end{array}$ \\
\hline $\begin{array}{l}\text { father junior high school } \\
\text { high school } \\
\text { two- year colleges } \\
\text { four- year universities }\end{array}$ & $\begin{array}{c}53.80 \\
27.74 \\
5.21 \\
13.26\end{array}$ & $\begin{array}{c}50.49 \\
33.60 \\
4.99 \\
10.92\end{array}$ \\
\hline $\begin{array}{l}\text { mother junior high school } \\
\text { high school } \\
\text { two- year colleges } \\
\text { four- year universities }\end{array}$ & $\begin{array}{l}53.51 \\
36.25 \\
8.32 \\
1.93\end{array}$ & $\begin{array}{l}58.90 \\
35.89 \\
3.97 \\
1.25\end{array}$ \\
\hline \multicolumn{3}{|l|}{ 2) Employment Status } \\
\hline & ASCLC & ESS \\
\hline $\begin{array}{l}\text { regular workers } \\
\text { self- employed } \\
\text { family workers } \\
\text { part time workers } \\
\text { non working } \\
\end{array}$ & $\begin{array}{l}26.09 \\
1.22 \\
5.97 \\
28.07 \\
38.65 \\
\end{array}$ & $\begin{array}{c}23.21 \\
5.66 \\
6.19 \\
23.06 \\
41.88 \\
\end{array}$ \\
\hline
\end{tabular}

\begin{tabular}{|c|c|c|}
\hline & ASCLC & ESS \\
\hline Professors and teachers & 3.90 & 2.47 \\
\hline $\begin{array}{l}\text { rudic neditrl drlu meuicall } \\
\text { innrlarc }\end{array}$ & 6.02 & 6.09 \\
\hline q(adoctors) & $(5 \%)$ & -- \\
\hline qonurses) & $(95 \%)$ & - \\
\hline Social and welfare workers & 5.80 & 1.84 \\
\hline qocare workers) & $(50 \%)$ & - \\
\hline qothers) & $(50 \%)$ & -- \\
\hline $\begin{array}{l}\text { Other professional \& technical } \\
\text { workers, and managers }\end{array}$ & 8.15 & 4.15 \\
\hline $\begin{array}{l}\text { Clerical, sales, and service } \\
\text { workers }\end{array}$ & 53.68 & 55.63 \\
\hline Others & 22.43 & 29.82 \\
\hline \multicolumn{3}{|l|}{ 4) Household's Total Income } \\
\hline & ASCLC & ESS \\
\hline less than $¥ 1$ million & 1.18 & 1.47 \\
\hline$¥ 1$ mill.- 2 mill. & 1.73 & 4.99 \\
\hline$¥ 2$ mill.- 3 mill. & 4.72 & 9.93 \\
\hline$¥ 3$ mill.- 4mill. & 8.40 & 13.83 \\
\hline$¥ 4$ mill. 6 mill. & 25.19 & 27.04 \\
\hline$¥ 6$ mill.- 8mill. & 23.59 & 20.14 \\
\hline$¥ 8 \mathrm{mill}$ - 10mill. & 16.72 & 11.24 \\
\hline$¥ 10$ mill.- 15mill. & 14.50 & 9.06 \\
\hline over $¥ 15$ mill. & 3.96 & 2.31 \\
\hline
\end{tabular}

Notes. 1) The Employment Status Survey of 1997 was conducted by the Statistics Bureau of J apan.

2) The number of observation in the ASCLC is 1476 wives, 1464 husbands, 2642 fathers and 2654 mothers. The comparison groups in the Employment Status Survey are 17 million wives under the age of 50, 15 million husbands under 50, 8 million men over 60, and 10 million women over 60. Household's income in the Employment Status Survey concerns about 28 million families whose head is under the age of 50 . 